$$
\begin{aligned}
& \text { SD } 427 \\
& . G 8 \text { P6 }
\end{aligned}
$$




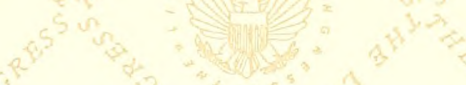

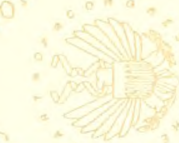
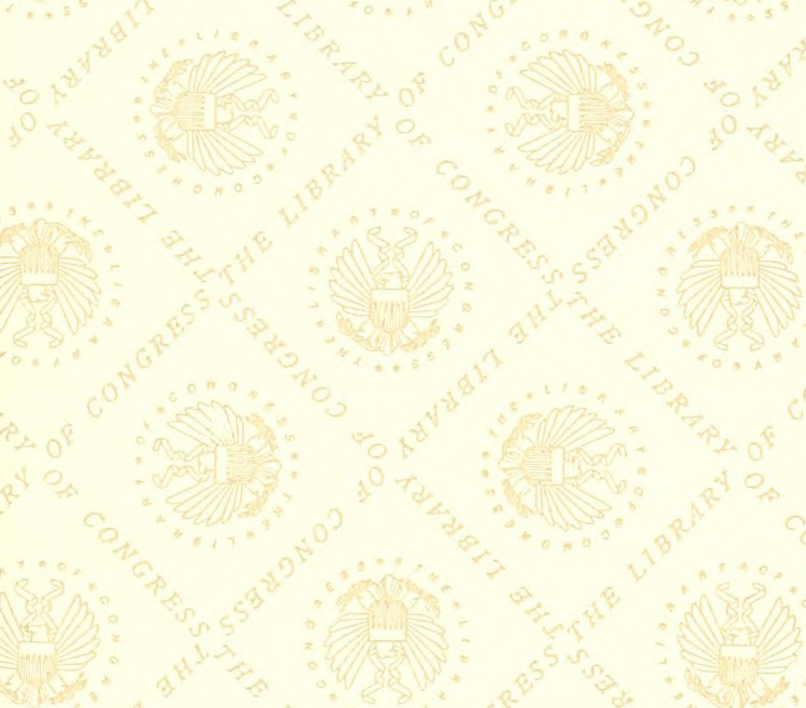

(
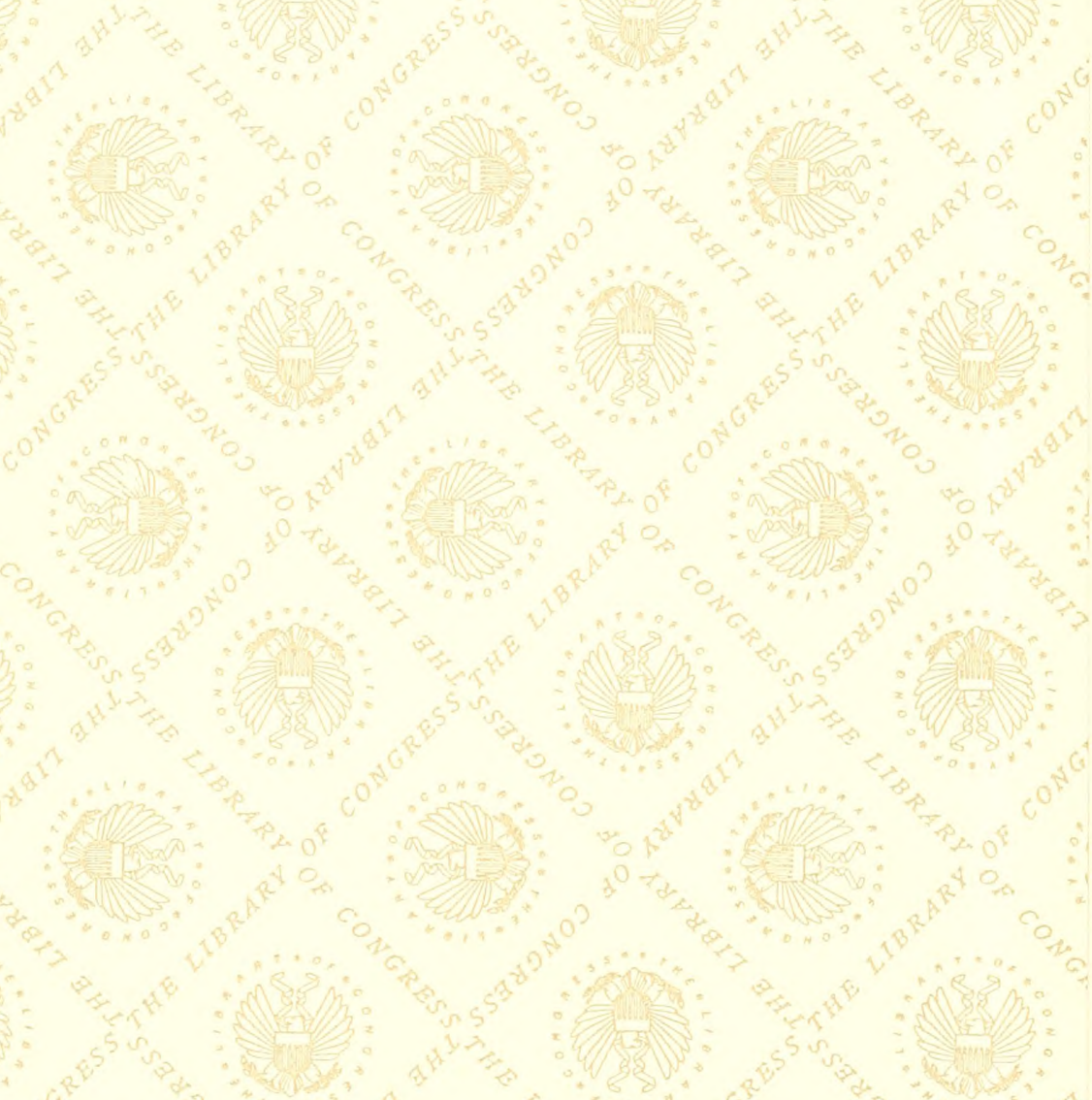

20

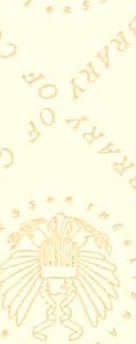

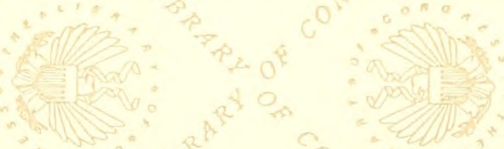
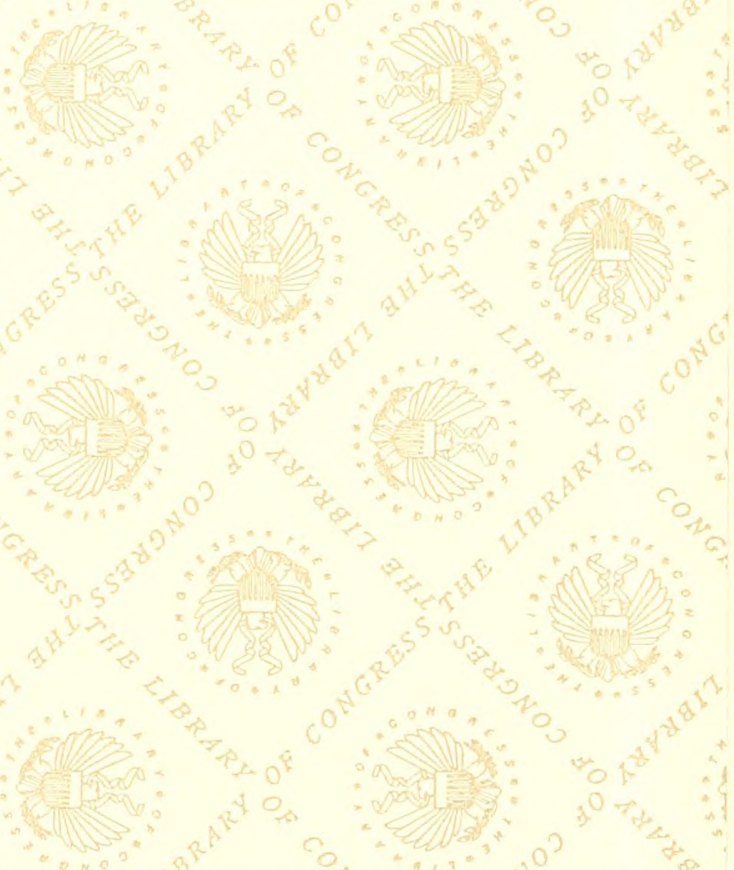


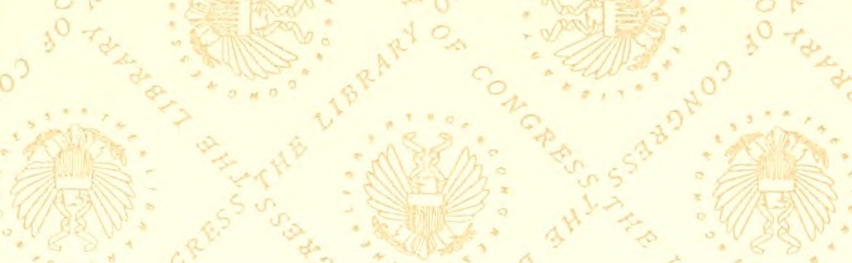
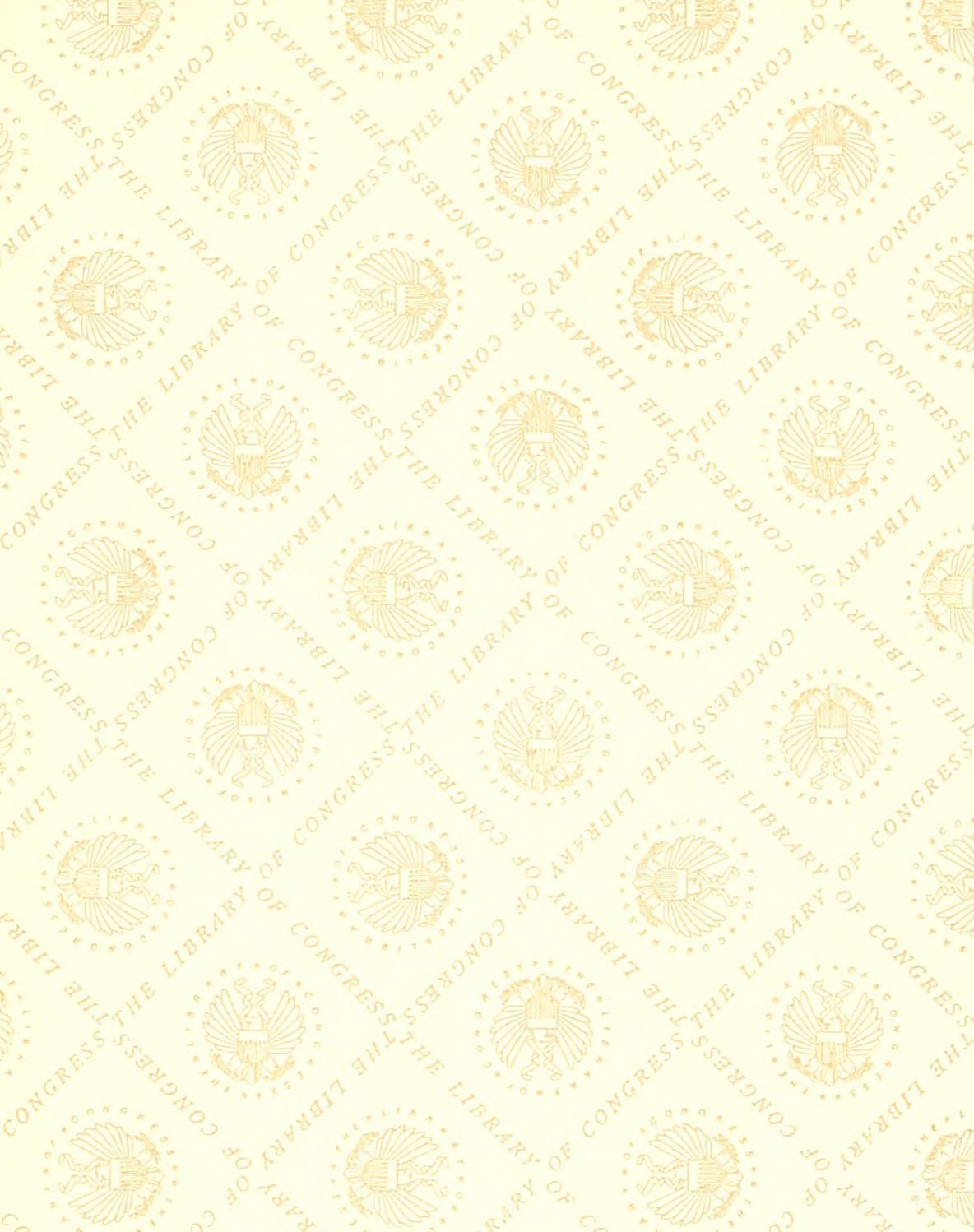

(3)
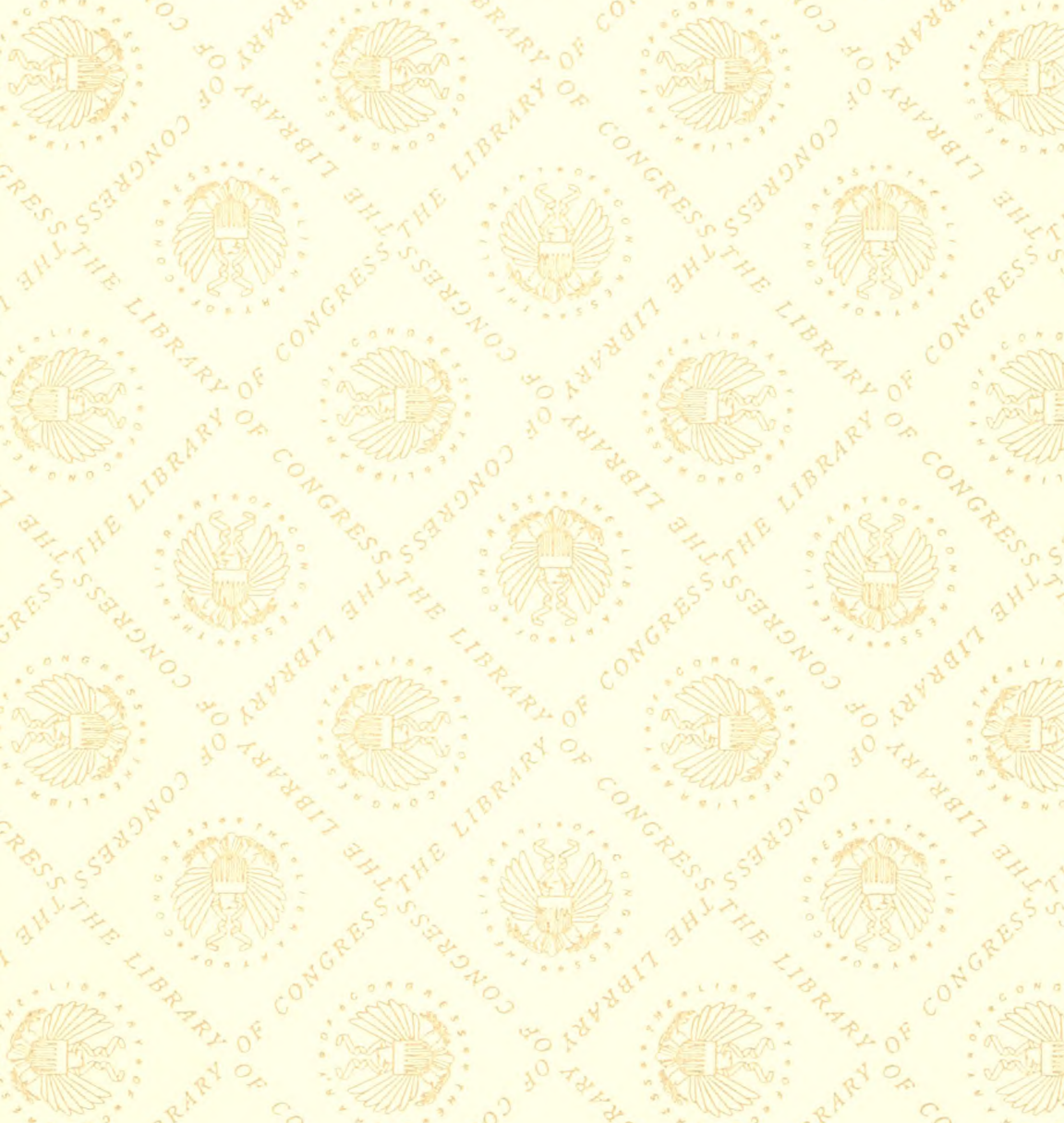



\title{
Administration of Grazing in National Forests
}

\author{
AN ADDRESS \\ DELIVERED BY \\ A. F. POTTER, Associate Forester \\ 1! In Charge of Grazing
}

BEFORE THE

Sixteenth Annual Convention of the American National Live Stock Association At Phoenix, Arizona, January 15, 1913

SHOWING:

Volume of Live Stock Grazing in National Forests Beneficial Changes in Regulation Through Co-operation with Stockmen

Improvements in Grazing Conditions

Increase in Value and Quality of Stock Greater Protection Given Small Stockmen

\section{By warissiat}

MAY 1 a93

PUBLISHED BY

AMERICAN NATIONAL LIVE STOCK ASSOCIATION

909 Seventeenth Street, Denver, Colorado

February, 1913 


\title{
OFFICERS
}

OF THE

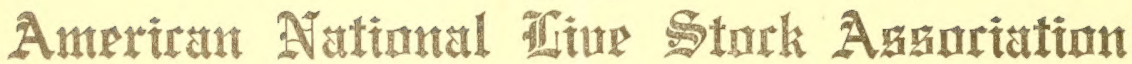 \\ FOR THE YEAR 1913}

\author{
PRESIDENT \\ H. A. Jastro . . Bakersfield, California \\ FIRST VICE-PRESIDENT \\ SI 427
}

Dwight B. Heard . . . Phoenix, Arizona

J. B. Kendrick VICE-PRESIDENTS

C. M. O'Donel .

M. K. Parsons

I. T. Pryor

Bell Ranch, New Mex.

C. B. Rhodes

Salt Lake City, Utah

San Antonio, Texas

Orchard, Colorado

John W. Springer. TREASURER Denver, Colorado

Sam H. Cowan. ATtorner . . Fort Worth, Texas

T. W. Tomlinson. SECRETARY Denver, Colorado

\section{EXECUTIVE COMMITTEE}

HUGH CAMPBELL........ Flagstaff, Ariz. F. T. COLTER.......... Springerville, Ariz. E. H. CRABB................ Flagstaff, Ariz.

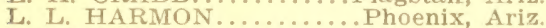
JAMES A. JOHNSON.... Williams, Ariz. CHARLES P. MUILEN.... Tempe, Ariz. W. H. NEEL.................................... Ariz. M. A. PERKINS............Junction, Ariz.

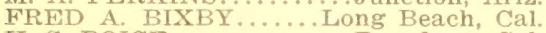

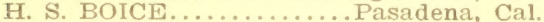
O. B. FULLER.............. Angeles, Cal. ROMIF JACKS... ........Monterey, Cal. H. W. KLIPSTEIN, JR...Maricopa, Cal. A. T. LIGHTNER........ Bakersfield, Cal. H. S. STEPHENSON.... Los Angeles, Cal. ISAAC BAER........................... D. D. CASEMENT. Colorado Springs, Colo. A. F. de RICQLES............ Denver, Colo. H. GLAZBROOK............. Higbee, Colo. WILLIAM GREmN........ Trinidad, Colo. JOHN MacBAIN........... Trinidad, Colo. M. J. GRAY................ Anthony, Idaho A. SYKES................ Des Moines, Iowa HORACE ADAMS..................... M. C. CAMPBELL...........Wichita, Kan. T. M. POTTER............................ W. J. TOD............. Maple Hill, Kan. ABRAM RENICKK.......... Winchester, Ky. F. C. HOUGHTON...... Corralitos, Mexico C. K. WARREN....... Three Oaks, Mich. W. D. JOHNSON....... Kansas City, Mo. R. J. KINZER............ Kansas City, Mo. L. F. WIISON.......... Kansas City, Mo. J. M. BOARDMAN...........Helena, Mont. WALLIS HUTDEKOPER.....Wallis, Mont. KENNETH McLFAN... Miles City, Mont. D. W. RAYMOND........... Helena, Mont. P. J. SHA NNON.......... Hamilton, Mont.

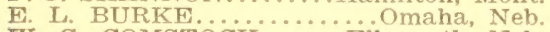
W. G. COMSTOCK........... Eilsworth, Neb.
A. H. METZGER.................. A. R. MODISETTE......... Rushville, Neb. ROBERT TAYTOR......................... Nebott, Neb. HARRY PETRIE...........Golconda, Nev. H. W. ADAMS...... Vermejo Park, N. M. GEORGE W. BATERR......Folsom, N. M. W. E. CURETON...... Steeplerock, N. Mt. W. H. JACK. . . . . . . . . . Silver City, N. M. W. C. MeDONALi D.......Carrizozo, N. M. C. W. MERCHANT......... Roswell, N. M. G. H. WEBSTER, JR..... Cimarron, N. M. G. HOW ARD DAVISON.. Millbrook, N. $\mathbf{Y}$. W. E. HALSELL............ Vinita, Okla. D. E. CIARK.................................... O. M. PLUMMER........ N. Portland, Ore. F. STEWART............... Dayville, Ore. BURTON C. MOSSMAN. Eagle Butte, S. D. P. H. O'NFIL...................... F. M. STEWART........Buffalo Gap, S. D. JULIAN M. BASSETT...Crosbyton, Tex. L. C. BRITE............................. Tarfa, Tex. S. B. BURNFTT........ Fort Worth, Tex. JAMES CALLAN.......Menardville, Tex. JOHN LANDERGIN..........Vega, Tex. FD. C. LASATER........ Falfurrias, Tex. J. H. NATIONS........................ Paso, Tex. J. H. PARRAMORE.................... AL POPHAM........................... W. D. REYNOLDS........ Fort Worth, Tex. A. B. ROBERTSON................... JAMES ANDRUS. .........St. George, Utah J. M. CUNNINGHAM....... La Salle, Utah ROBERT D. CAREY.... Careyhurst, Wyo. W. C. IRVINE...........Cheyenne, Wyo. A. R. READFR............. Dixon, Wyo. W. M. SPEAR............. Sheridan, Wyo. J. C. UNDERWOOD.... Underwood, Wyo. C. N. WATTERS........... Buffalo, Wyo.

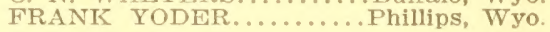

\section{OFFICE OF THE ASSOCIATION




\section{TO THE CONGRESS OF THE UNITED STATES}

BY RESOLUTION OF THIS ASSOCIATION, IT WAS ORDERED THAT THIS ADDRESS OF MR. POTTER'S BE TRANSMITTED TO CONGRESS, "WITH THE STATEMENT THAT THE INFORMATION CONTAINED THEREIN, RELATIVE TO GRAZING IN THE NATIONAL FORESTS, IS IN COMPLETE ACCORD WITH OUR KNOWLEDGE, AND THAT THE GENERAL ADMINISTRATION OF THE GRAZING IN THE NATIONAL FORESTS AND THE PLANS FOR IMPROVEMENT THEREOF MEET WITH OUR ENDORSEMENT."

IT IS BECAUSE OF THE SUBSTANTIAL BENEFITS TO THE ENTIRE COUNTRY, AS WELL AS TO THE STOCKMEN, FLOWING FROM THE FEDERAL ADMINISTRATION OF THE NATIONAL FORESTS-SUCH AS ELIMINATION OF RANGE DISPUTES, CONSERVATION OF GRASSES, INCREASED CARRYING CAPACITY OF THE RANGE, AND THE GENERAL SATISFACTION OF THE GREAT MAJORITY CONCERNED-THAT THIS ASSOCIATION STRONGLY URGES SIMILAR CONTROL OF THE SEMI-ARID, UNAPPROPRIATED, PUBLIC GRAZING LANDS, BY LEASE OR OTHERWISE, UNDER THE JURISDICTION OF THE DEPARTMENT OF AGRICULTURE OR THE DEPARTMENT OF THE INTERIOR, AS PROVIDED IN H. R. BILL NO. 19857, NOW PENDING BEFORE THE COMMITTEE ON PUBLIC LANDS IN THE HOUSE OF REPRESENTATIVES. SUCH FEDERAL ADMINISTRATION OF THE SO-CALLED OPEN RANGE WOULD, WE CONFIDENTLY ASSERT, LARGELY INCREASE THE PRODUCTION OF LIVE STOCK IN THE WEST. WE INVITE ATTENTION TO THE FOLLOWING RESOLUTIONS, UNANIMOUSLY ADOPTED BY THIS ASSOCIATION AT ITS ANNUAL MEETING AT PHOENIX, ARIZONA, JANUARY 15, 1913, WHERE EVERY IMPORTANT LIVE-STOCK ASSOCIATION OF THE WEST WAS REPRESENTED. WE ALSO INVITE CAREFUL CONSIDERATION TO THE EXTRACT FROM THE ANNUAL ADDRESS OF HENRY A. JASTRO, PRESIDENT OF THIS ASSOCIATION, ON THIS IMPORTANT SUBJECT.

RESPECTFULLY SUBMITTED,

EXECUTIVE COMMITTEE, AMERICAN NATIONAL LIVE STOCK ASSOCIATION.

T. W. TOMLINSON,

SECRETARY. 
INDORSING THE ADMINISTRATION OF NATIONAL FORESTS.

We believe that the administration of the national forests throughout the West is conducted along most efficient and just lines. Many matters of detail, which at first occasioned some discontent among stockmen, have been satisfactorily adjusted, or are being remedied with consistent rapidity, and there is a very evident intention on the part of the officers of the service to manage the forests so as to obtain from them the greatest amount of reasonable use consistent with their preservation. The American National Live Stock Association, in convention assembled, at Phoenix, Arizona, January 14 and 15, 1913, therefore heartily indorses the administration of this service as being of distinct advantage to the stockmen of the West.

We further believe that the live stock industry is best served through ownership and control of the national forests by the federal government, and we are opposed to any proposition which contemplates their transfer to the states.

URGING FEDERAL CONTROL OF THE UNAPPROPRIATED AND UNEESERVED SEMI-ARID GRAZING LANDS.

The American National Live Stock Association, in convention assembled, at Phoenix, Arizona, January 14 and 15, 1913, hereby declares that:

We believe that the prosperity and development of the stock-raising industry on the public grazing lands of the arid and semi-arid West is seriously threatened by the present indiscriminate methods of grazing, and that thereby the permanent value of such lands is greatly impaired, and we strongly recommend the early passage by Congress of a bill providing for federal control of these unappropriated public grazing lands and a just and reasonable method of leasing such lands.

We favor a bill to operate either under the jurisdiction of the Department of the Interior or of Agriculture, and along the general lines definitely recommended by this organization at its annual convention in Denver in 1908, and approved at all its conventions since that date. This measure would be of great practical advantage to the stockmen and farmers of the West; would give full protection and encouragement to the actual settler and home-maker, and, through the distribution of the net revenues received in the construction of schools and good roads in the districts from which the funds are obtained, would be of great public benefit. We also vigorously urge Congress to provide without delay for the classification of the unappropriated unreserved public lands into grazing and agricultural districts. 


\section{Co-operation in Range Management}

Mr. A. F. Potren: Mr. President, Ladies and Gentlemen-The administration of grazing in our national forests involves many different phases, and I am going to talk to you mainly this morning about "Co-operation in Range Management."

The success which the Forest Service has had in regulating the use of the range, and in bringing about more satisfactory conditions in the national forests, has been due very largely to the hearty co-operation it has received from the stockmen. One of the first steps taken after the transfer of the national forests to the Department of Agriculture was to request the associations representing the owners of the different kinds of live stock to appoint a committee to meet with members of the Forest Service for the purpose of discussing proposed changes in the grazing regulations.

The invitation was accepted, and a conference was held at Denver, Colorado, in December, 1905. This brought out many good suggestions from the stockmen, and led to the adoption of a definite policy which was to govern the regulation of grazing in the national forests. The most important points were: (1) that priority in the use of the range would be recognized, and the grazing privileges in the beginning allowed those who were already using the range; (2) that any changes which were found necessary, either in the number of stock grazed or in the methods of handling it, would be made gradually, after due notice had been given; (3) that small owners would be given a preference in the allotment of permits, and be exempted from reduction; (4) that the checking of damage to, and the improvement of, the forest would be brought about so far as possible without total exclusion of the stock; (5) that the forage resources of the national forests would be used to the fullest extent consistent with good forest management; and (6) that the stockmen would be given a voice in the making of rules for the management of their stock upon the range.

Recommendations were made to the Secretary of Agriculture, which resulted in the promulgation by him, on March 31, 1906, of a regulation providing for the recognition of advisory boards representing associations whose members were users of the forests, such boards to be entitled to receive notice, and have an opportunity to be heard in reference to increase or decrease in the number of stock to be allowed for any year, the division of range between different kinds 
of stock, or the adoption of special rules to meet local conditions. Under this regulation, eighty-four advisory boards, representing the stockmen using the national forests, have been recognized, and are now co-operating with the Forest Service in an effort to bring about better conditions in the live-stock industry and the best possible use of the range.

At this time it might be well to call attention to the extent of the forage resources in the national forests, in order that the importance of their use may be realized. Approximately 75 per cent of the national-forest land, or about 110,000,000 acres, is, or may be, used for the pasturage of live stock. The lands covered by the more open stands of timber, the exposed slopes of otherwise timbered hills or mountains, the narrow valleys along the streams, the areas above timber-line, and the eut-over or burned-over areas, all produce crops of forage, and are particularly desirable grazing grounds for cattle, horses, swine, sheep, and goats, during the seasons of the year when the various areas may safely be used.

The money value of this forage crop is enormous. Each year the treasury of the United States is enriched to the extent of almost one million dollars, which is paid by stock-growers for the privilege of grazing their stock upon the national-forest lands. Each year the stock grazed under permit produces beef, mutton, wool, hides, and pelts to the value of more than thirty millions of dollars. Throughout the western states there are innumerable communities whose welfare and general prosperity are vitally dependent upon the systematic utilization of the forage products of the forest lands. The favorable effect which these low-priced and permanently productive ranges have upon the general question of meat supply and cost to the consumer is too pronounced to be doubted, and is of first importance to every consumer of meat products.

During the grazing season of 1912 the national forests provided pasturage for approximately 14,000,000 head of stock. More than 100,000 head of milch and work stock were grazed free of charge and without permit by settlers within and near the national forests. Permits for which a fee was paid were issued, allowing the grazing of 1,403,025 cattle, 95,345 horses, 4,330 swine, 7,467,890 sheep, and 83,849 goats. The natural increase of this stock, for which no permit or fee was required, amounted to approximately 300,000 head of calves and colts, 5,000 swine, and 4,000,000 head of lambs and kids-nearly $14,000,000$ in all. In addition, forage was provided for 89,877 head of cattle and horses, and 5,174,052 head of sheep and goats, while this 


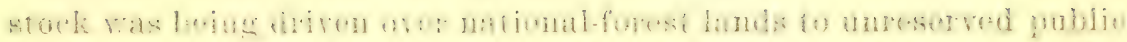

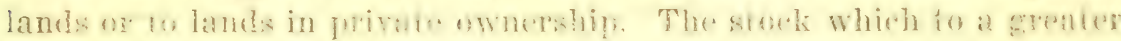

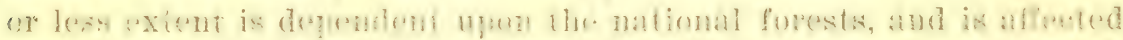

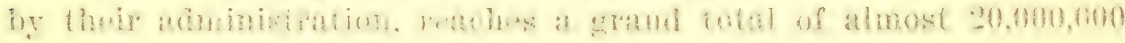
head each year.

The national forests have been established primarily for the

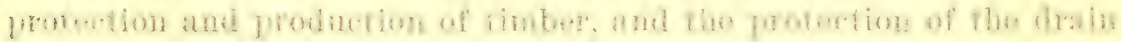

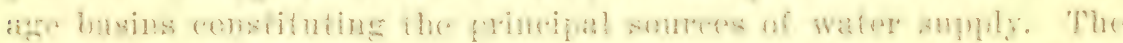

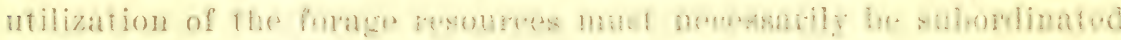

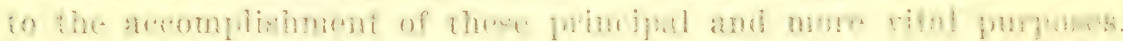

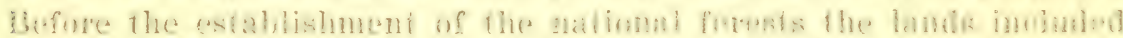

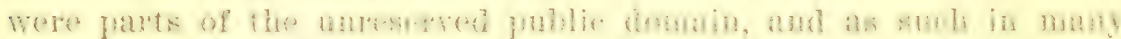

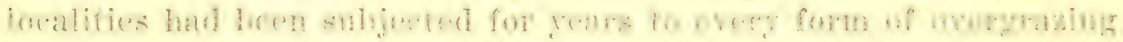

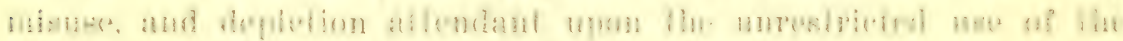

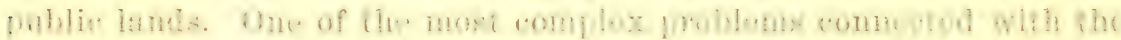

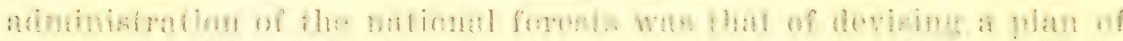

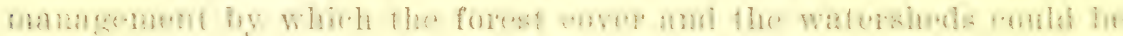

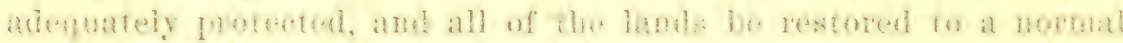

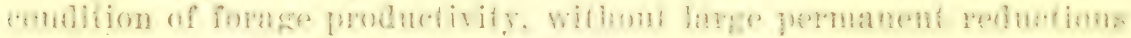

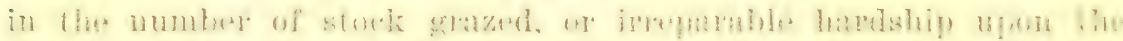

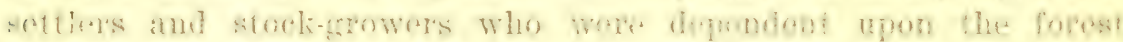
ranges for the maintenance of their homes.

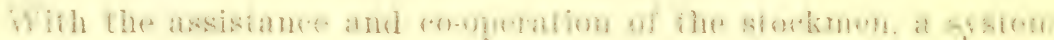

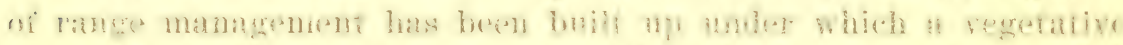

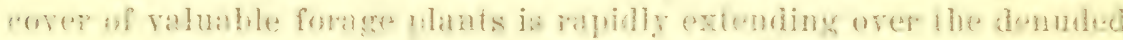

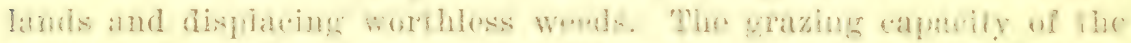

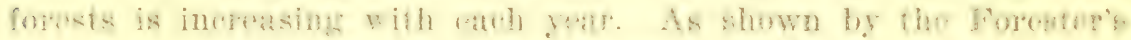

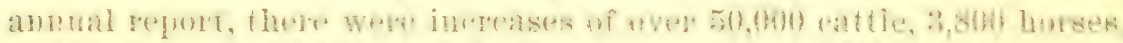

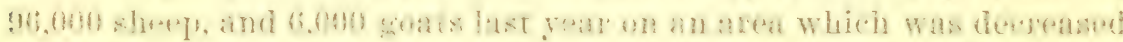

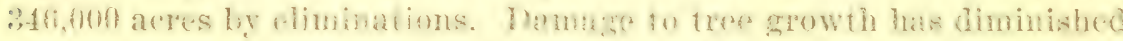

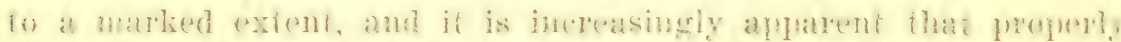

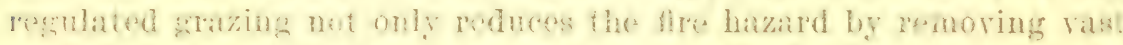

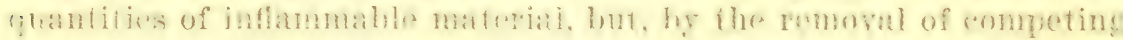

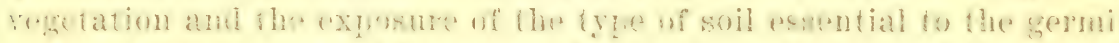

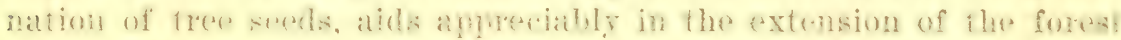

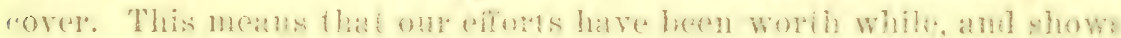
what can be accomplished by earnest co-operative work.

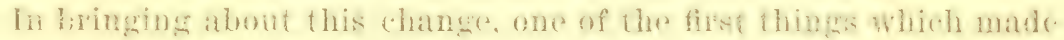

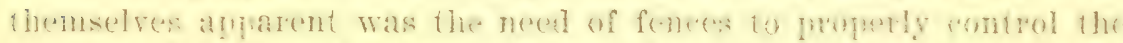

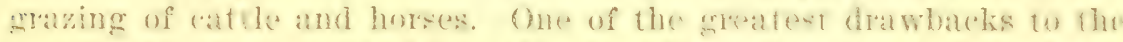
moneratth husiness had hern the loss from straping, and the large 
amount of riding which must be done to prevent it. Fences were needed to keep the cattle upon their natural ranges and to enable

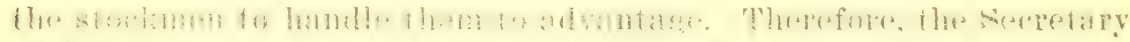

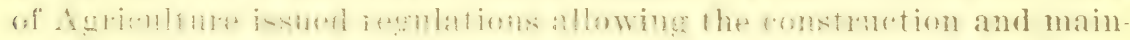
tenance of drift and division fences upon the national forests. This

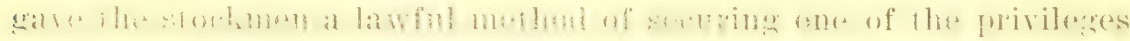
which tere most needed for the success of their business. Where

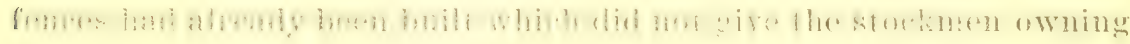
them more than a fair share of the range, they were allowed to remain. Where new fences were needed the stockmen were permitted to construct them. Whenerer these fences wonld materially assist in the administration of the forest. posts and poles were given free of charge, and in many cases also the wire and staples. In co-operation with the stockmen, the Forest Service has constructed over 650 miles of drift fences, and over 1.500 permits hare been issued to stockmen for the maintenance of fences on the national forests.

In addition to drift fences, the stockmen also needed small pastnes for saddle borses, for use in wathering stock for shipment, find for pure-bred stock. Sitrictly spealking, the construction of these pastures cannot be classed as co-operative work, as the government bas made no actual contribution to the cost of the fences. Still, by classifying and sureying the laud suitable for pasturage purposes, and by granting the exclusive use of such lands under permit, the gorermment has made it possible for the stock-grower to protect himself against many of the hazalds of the indrustry, and to greaty lessen the eosts of handing his storek. Almost 5, 000 permits of this class have been issued, and the mationalforest lands enclosed within pastures amount to orepe 500,000 areres.

Where the ranges were orerstocked to an extent which was (ausing damage, one of three things had to be done: Wither the growth of forage on the lands muder use had to be increased, new areas oryened to grazing, or the number of stock reduced. Areas not in use were mostly manges which were inacessible on account of the absence of the trails or bridges needed for stock to reach them, or because of the lack of a water supyly. The Forest Service immediately took up the problem of opening these ranges aud, as funds were available, began the construction of the necessary improvements. In this work, as in all other ways, the stockmen have given hearty co-operation and assistance. All told, a total of over 13,000 miles of trails have been constructed in the national forests. In addition to making may areas of rirgin range accessible to stock, this has facili- 
tated the movement of stock in and out of the forest, to and from shipping points, and from feed to water, and has enreatly reduced the difficulty of securing supplies.

Since 1908 the forest Service lats developed orel son somees of

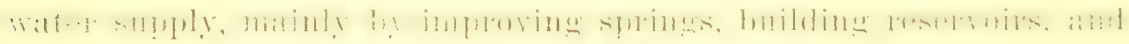
opening trails to inaccessible waters. During the same period orer ino somices of water supply were developed under permit by stockmen. Of these, about 570 were for reserroirs or tanks, and 180 for the development of springs and sinking of wells. While the Forest serrice exceeded the stocli-growers in number of projects, it is probable that the anmont expended by it mas less than that spent hy the stockmen. Bridges were not strictly a range improrement, but they contribute greatly to the use of the range, and you will be interested to know that orer :'S0 bridges have been built by the Forest Serrice.

One of the stockman's meatest enemies is the predatory wild mimal. Hundrels of thousands of dollats' worth of live stock are destroyed each year by wolves, coyotes, and mountain lions. It has been the desire of the Forest Fervice to assist in every possible way in the extermination of these pests. The forest rangers and guards have been supplied with traps and ammunition, and in lonalities where it was known that the depredations were serious. practical hunters have been employed as guards, and hare spent their entire time in hanting predatory animals. The result has been that during the past four years forest oflicers hare actually killed and found the bodies of over 27.500 molves, coyotes, lions, bears, lynxes, and wild cats. These figures do not include the animals shot or poisoned but not found, and therefore it is safe to say that orer :30,000 jredatory amimals have been killed: and the reduction in stock losses effected by this means has gone far to compensate the stoch-growers for the mazing fees ther have paid. Requests have been made that the Forest service extend its co-oneration to the parment of bounties, but it has been unable to do so for the reason that there is 110 law which anthorizes sueh action.

Last August a hill was introduced in Congress by Senator Catron,

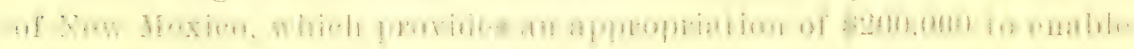
the Secretary of inliculture to co-operate with any state containiug mational forests which shall provide by law for the destruction of predatory wild animals, in the organization and maintenance of a plan for the destruction of such animals upon the national forests. muler the condition that the state shall expend a proportionately equal amount. On the day following the introduction of this measure in the senate, Mr. Mondell, of Wroming, introduced a similar bill in the 


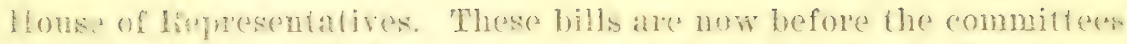
of the two bronules of Congues, and without question will be given

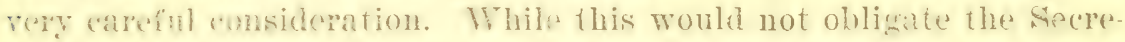

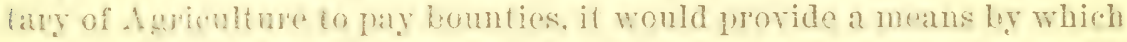
he eouble do se if it was deemed adrisable. It is a well-recognized

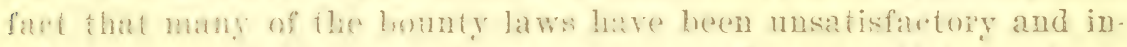

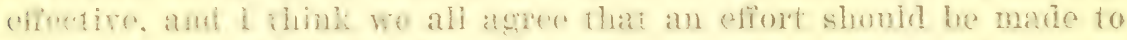

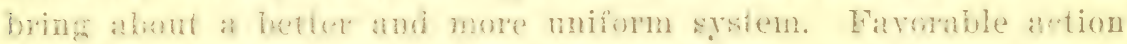

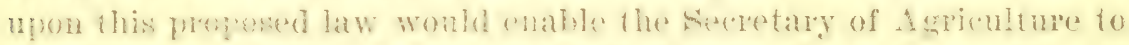

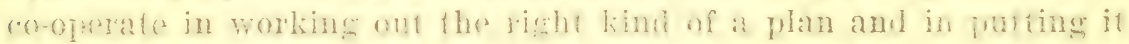
into effect.

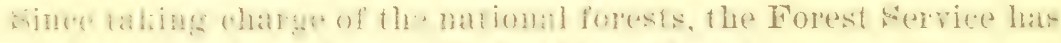

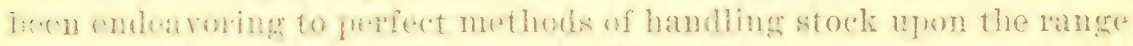

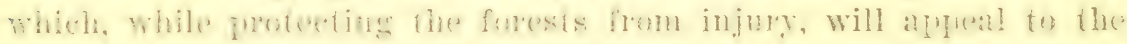

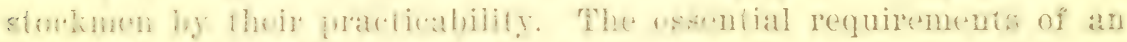

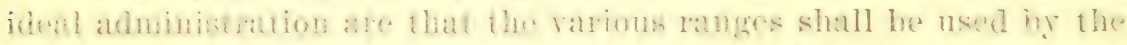

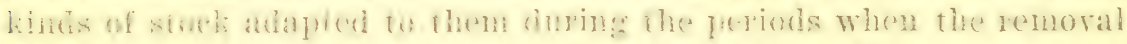

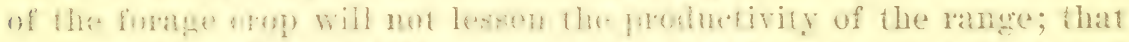

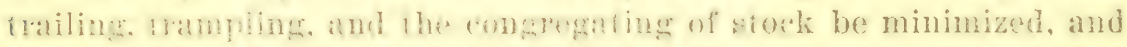

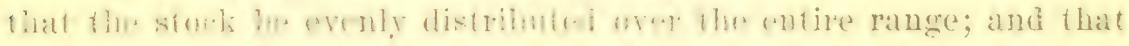
the ranges be used in rotation, so that within every two or three yous carh pontion shall have mpontmity to reseced itself. With

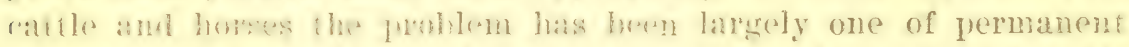

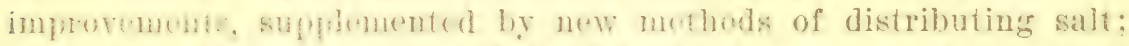

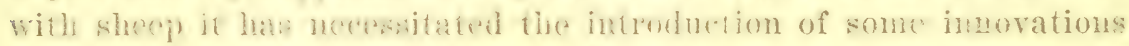

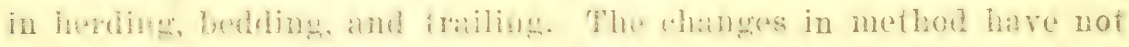

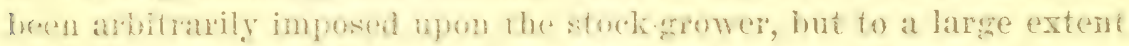

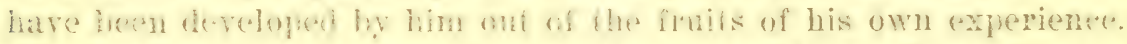

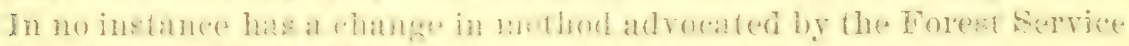

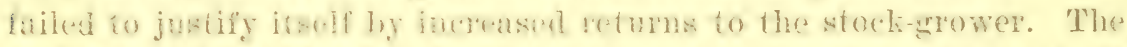

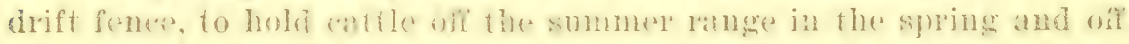
the winter langer in the fall: the newly dereloped waterloble, dim-

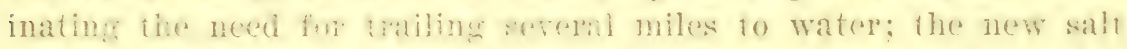

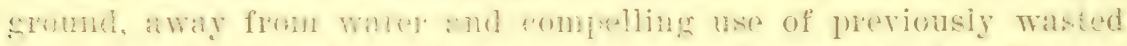
feed; the dividing fomer betrexen steres and stock caltle, all have

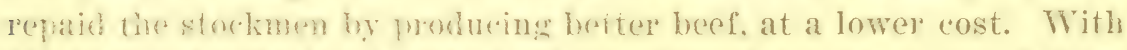

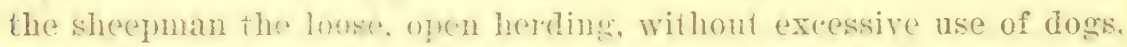
and he hedeling of res shep where night orertakes them, rather than the retum over harren trails to semi-jermanent camps, have resulferd in better ranges, better sheep, and larger profits. 
It is an old saying that "money lalks," and I am going to take

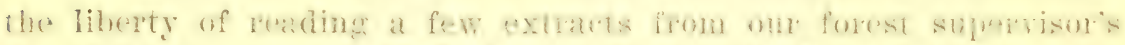

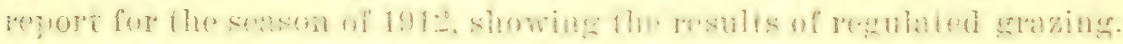

From the Humboldt Forest in Nevada it is reported that, when

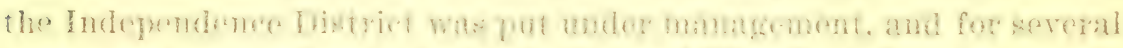

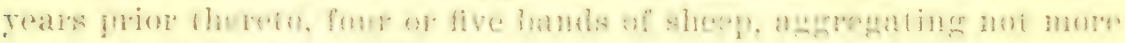
than 10,000 head, and those not doing rery well, was the extent of

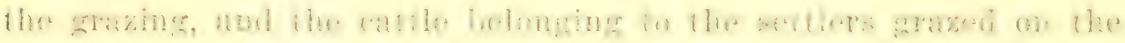

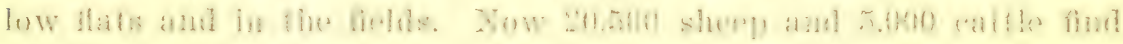
excellent grazing during the entire season.

From the Bearer Head Forest in Montana it is reported that

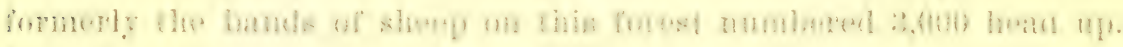
Now they do not number orer 1,600 ewes and lambs, or 2,100 dry

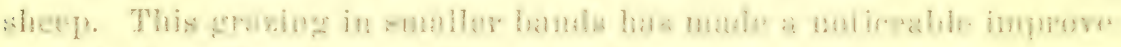
ment both in the range and the condition of the lambs.

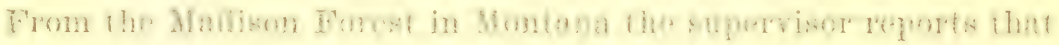

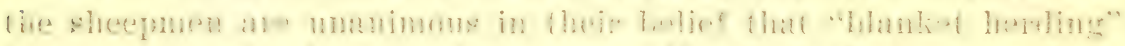
is increasing the feed on fige rangos. Alr. T. D. Jenkins, of Twin

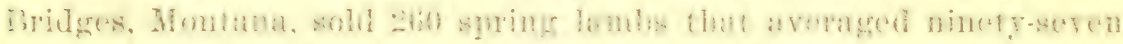

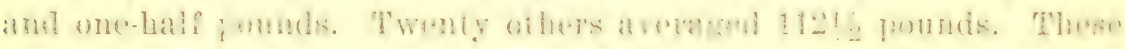

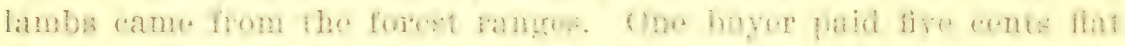

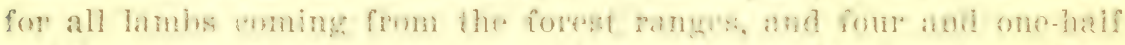

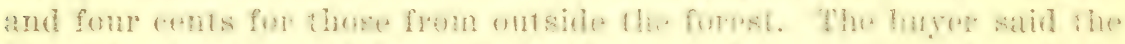
forest lambs areragen from six to nine pontmin more than the othere.

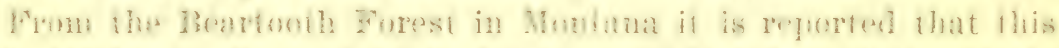

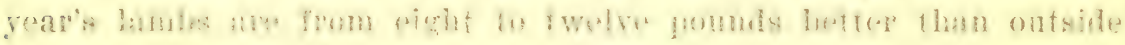
lambs.

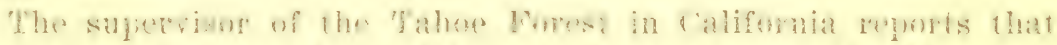

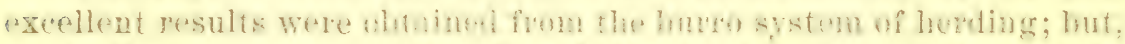

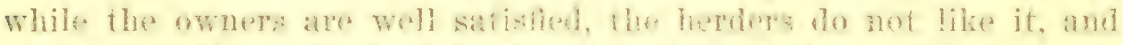
only follow the mothods under the direst eye of the owners.

Qn the Modoc Horest in california it is reported that out of fiffy.

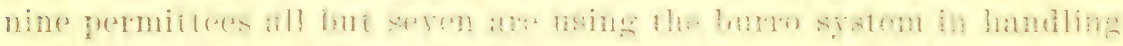
thoir hards. There has leen a great impletrement in the rarying

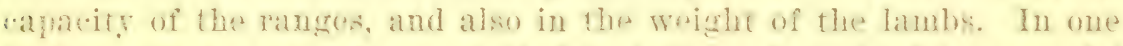
instane the owme infortise us that he helieves le cained fen pound: weight on each of his lambs.

From the wan Isobut Forest in coloraro it is reponted that fue Tomplins Cattle Company sold joo three-year-old steers, half

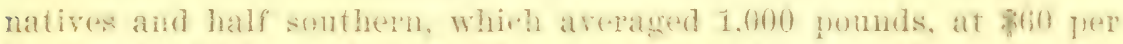

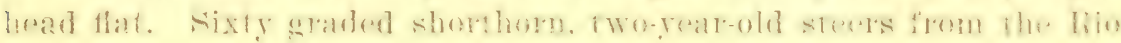




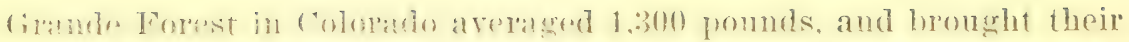

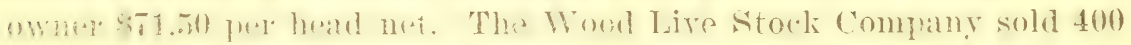

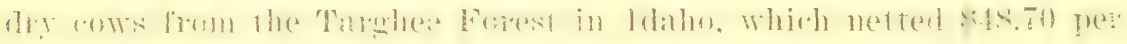
head.

From the detherson Forest in Montana it is reported that Mr. H. X. liati. of Twa hot. Montana. sold a humeh of steers whirh areraged

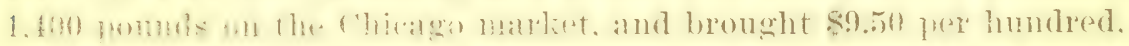

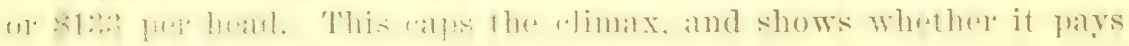
to regulate the use of the range.

In conclusion, I wish to say that it is our aim to continue a con-

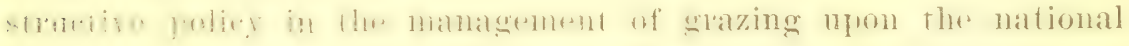
forests, and to use every effort to bring about a better and more (*hily)

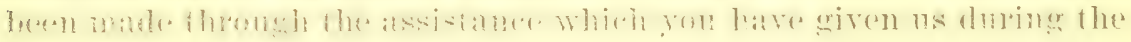
past, and with a continuance of rour co-operation I am sure that we shall be able to malie further improvement and to better meet the needs of the live-stouk industry. (1pplause.) 
EATRACT FROM ANNUAL ADDRESS OF H. A. JASTRO, PRESIDENT, AT THE SIXTEENTH ANNUAL CONVENTION OF THE AMERICAN NATIONAL LIVE STOCK ASSOCIATION, AT PHOENIX, ARIZONA, JANUARY 14 AND 15, 1913.

The establishment of the national forests, and the grazing thereon under federal supervision, have met with general approval in this state as elsewhere, and I do not believe that the permanently established stoclimen of Arizona, using these reserves, would be willing to return to the old system. Some similar administration of the open ranges of Arizona would, I am confident, meet with equal favor, and would add prosperity to the live-stock industry. Not only would it mean stability to the range business, but it would be an incentive to the users of the range to rest and reseed the ranges, which method would in time result in an increased production of live stock. This has been demonstrated beyond any contradiction by the very thorough experiments conducted at the Experiment Station in Tucson regarding the regeneration of the range grasses. Under a lease law, the country now used for nomadic grazing would be converted into a prosperous breeding country instead of a half-waste. I will not dwell longer on the merits and necessities of the lease law as applied to the semi-arid open range, for this is one of the leading questions for discussion at this meeting, and you will hear some very interesting talks regarding it. I wish, however, to comment on the economic side of the lease-law proposition.

The United States has today less live stock per capita than ever in its history. Various reasons have been advanced for its shortage. Indeed, there are many causes which, in a greater or less degree, have contributed to bring it about. But of all the influences which have tended to lessen the production of live stock in the West, I believe the most potent is the very unsatisfactory range conditions arising out of indiscriminate grazing, and the scramble to secure what is left of the already depleted ranges. There is no business in the country so fraught with harassing and annoying difficulties as the handling of cattle under a free-range regime. Therefore, stockmen quickly (mbraced the opportunity to quit the bisiness as soon as prices for stock warranted them in doing so. In my judgment, this is the chief cause why the free-range states of the West have so few cattle today.

Congress is now trying, through the removal of the import duty, to cheapen the cost of live stock and meat in this country. This may give some temporary relief-and of that I am quite doubtful; but I am certain it will not cure the evil. The trouble is deeper-seated than the tariff, and is chargeable to the indifference of Congress to the needs of the West, and to its failure to pass adequate laws protecting and conserving western ranges.

This is not a new question. It has been agitated for many years. As early as 1900, at the annual convention of this Association in Fort Worth, Texas, a resolution was adopted urgine congress to classify and lease the semiarid public grazing lands of the West. In 1903, at the annual meeting in Kansas City, this Association memoralized Congress to appoint a special latnd Commission to investigate western land conditions. Pursuant to that monorial. the President of the United States appointed a Land ('ommission, which met in Denver, with 105 representative stockmen of the West, in a three days' con- 
ference, in August, 1904, at which meeting $I$ was present. That conference favored a classification of the public lands, and government control, by lease

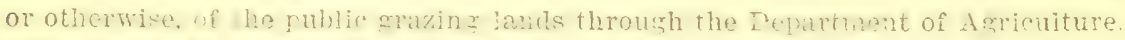

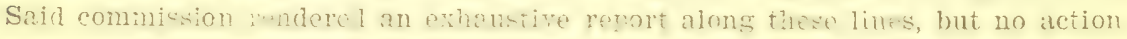
was taken by Congress.

In January, 10ms, our Association formulated a specific bill for the leasing

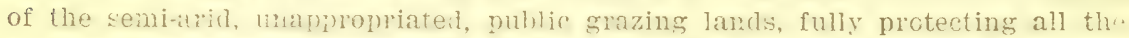
rights of the homesturler. That hill, with some slight molifieations, has been introduced in both branches of Congress every session since 1908. None of the bills were ever reported out of the committees to which they were referred. In fact, there have been various bills designed to solve this land question introduced at every session of. Congress for the past fifteen years. Last summer lengthy hearings were held in May and July, before the Committee on Plablic Lands of the House of Representatives, on II. R. Bill No. 19S57, known as the Lever Bill, and endorsed by this Association. Despite our efforts to have this bill reported favorably, it still lies dormant in that committee, as other bills have in previous sessions. In the past decade there have been land conventinus which have considsped and resolutei nn this question; governors of the western states have conferred about it; and while many different remedies were proposed, no definite action has been taken, although there seems to be no division of sentiment on the point that some legislation must be had for the live-stock industry to derive the full benefit of the open range.

The great difficulty in securing this much-needed legislation lies in the fact that the West is divided on the question. The majority of the stockmen of the West favor a law similar to that formulated by this Association, and tilose stopinen who ojpos it an mostly nomalic stocimen who lrofit by mes ent exiucinz conditions. Then there is the opposition of those who think all the government land should be turned over to the state in which it is located. As the states have always followed the plan of leasing state lands, they would probably do the same with any open-range land turned over to them by the

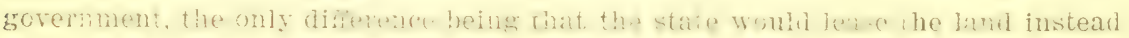
of the federal govermment. Those who have had experience with both incline to the belief that the federal government would more equitably handle the land than the different states. However, the claim of those who want the land turned over to the states need not be seriously considered, because there is no likelihood of eastern legislators agreeing to such a disposition. Some others insist that a lease law would impede settlement of the West, and interfere with the rights of homesteaders. On the contrary, the history of the operation of lease laws all over the world proves that they promote the settlement and development of the country. That was true in Texas, and it will be true of other states,

In view of this varied opposition on the part of some of the people of the West, it is not strange that western congressmen and senators should also entertain divergent views; for, as a rule, congressmen try to please their constifinuts and to offend none of them; so that explains thrir inartivity on this question.

The land problem is strictly a western one, and representatives in Congress from all other sections claiming to have no direst interest in this matter have always preferred that any measures concerning range legislation should ema- 
nate from our wostem representatives. And, for the reason I have nentionedthat our western sonators and conmrsman will not unite on any plan that will suit the majority of them-Congress bas been dilatory in acting upon this

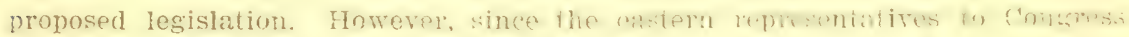
have become more familiar with the siturtion, and this question has now become nation-ivide, I believe that at this time we shoutd urge all representatives in Congress and all senators to take up this matter in earnest, and enact some laws that will result in the greatest good to the greatest number. There will always be smme oplosition; that is true of every bill that massas Congress. Unanimity of opinion on this or any other subject is almost unattainable.

It being evident that the shortage of live stock in the West is in a great descee traceable to the mresent range conrlitins, I holve mu Congress will awaken to a just conception of a situation which we have sought for many years to make blain. The legistation wo ask for concems the Fass as much as the West; the consumer as well as the producer. It has been pigeonholed in romanittae-rooms loug enough. I hope this convention will fass same strong resolutions on this important question, and that you will follow them up by again sending a strong remresentative commitice to "Vashington to urge the passame of this much-needed legislation. 


$$
m_{R} D-2 z
$$




00028890394 